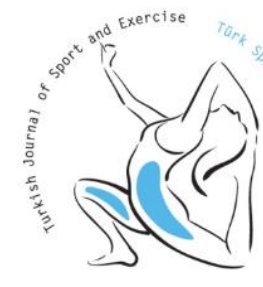

ISSN: 2147-5652

\title{
Analysis of badminton competitions in 2012 London Olympics
}

\section{Mert AYDOGMUS', Erkal ARSLANOGLU², Omer SENEL ${ }^{3}$}

\author{
${ }^{1}$ Hasan Doğan School of Physical Education and Sports, Karabük University, Karabük, Turkey. \\ ${ }^{2}$ Sarıkamış School of Physical Education and Sports, Kafkas University, Kars, Turkey. \\ ${ }^{3}$ School of Physical Educat,on and Sports, Gazi University, Ankara, Turkey. \\ Address Correspondence to E. Arslanoğlu, erkaloglu@gazi.edu.tr.
}

\begin{abstract}
In this study, the general analysis of 2012 London Olympics Badminton matches are aimed to be made. In this analysis, the physical characteristics of the Olympic players, the average match and rally durations, the countries which have participated by rally stroke points and the distributions of the medals were studied. The official website of 2012 London Olympics were used as a means of collecting data and during the matches, the results and analysis of a total 189 matches published on this site were recorded and evaluated. The study was carried out by using the data which belong to a total of 170 players ( 90 women and 80 men) who participated from 52 countries. Descriptive statistical analysis of data (mean, standard deviation, minimum and maximum values, percentage distribution) was done by using SPSS 17.0 for Windows. As a result of this research, the mean total match duration in singles and doubles categories were determined as; for males $45.12 \pm 13.24$ minutes, $39.37 \pm 11.46$ minutes, for females $37.7 \pm 12.46$ minutes, $42.27 \pm 8.94$ minutes respectively. The longest rally mean durations of competitions in man and women singles were respectively $38.4 \pm 16.22$ seconds, $34.6 \pm 8.15$ seconds; in men doubles, in women doubles and in mix doubles were respectively $38.18 \pm 15.13,48.16 \pm 11.8$ and $23.19 \pm 9.15$ seconds. When the highest rally strokes, with average of $53,39 \pm 15,7$ strokes, took place in the women doubles, it was followed by women singles $(41,39 \pm 10,6)$, men singles $(38.66 \pm 13.26)$, men doubles $(36.74 \pm 12.58)$ and mix doubles $(35.43 \pm 8.67)$. When looked at the data obtained in this study, it is observed that the highest mean match durations are in men singles and the longest mean rally durations and the highest mean rally strokes are in women doubles categories. As a conclusion, according to the 2012 London Olympics analysis, badminton coaches must revise technical, tactical, conditional elements of badminton and they have to prepare special schedules for category properties.
\end{abstract}

Key Words: Badminton, 2012 London Olympic Games, match analysis.

\section{INTRODUCTION}

Badminton is a sports activity characterized by its continuous high density during games, its long durations and its periodical brakes (9). After badminton was represented officially in the 1992 Barcelona Olympics, the performance capabilities of the players became the focus of the researches. Despite having an old and rooted historical background, we cannot say that it is as widespread as expected in our country. It has a very short historical background in Turkey (the foundation of Turkey Badminton Federation is 1991). However, the development and promotion facilities are rapidly continuing. Besides, badminton takes place in the most preferred free time activities. Since the playground could be set up easily and since the amateurs could easily start playing it, people are interested in these sports (8).

In badminton, as in the other sports which use racquets, there are short-termed maximal and submaximal overloading and short-termed resting periods. In such sports, speed, coordination, strength, reaction, instinct, game skills and technics are considered as preconditions of success (4). In highlevel competitors, high level aerobic capacity is needed (10). The duration of a badminton match changes between 15-90 minutes depending on the performance of the players and the number of the rounds played $(6,13)$. 
From time to time, so as to make the conditions of the game more appealing, to improve the visual quality and to increase the number of sponsors and audience, International Badminton Federation (IBF) makes some changes on the rules. From these, the changes in the score system are the most attractive one. When it was 15 in all the categories in 2004 Olympic Games, the game was played over 21 round score and by changing the service system, each mistake was counted as a point in 2008 and 2012 Olympic Games. Again since the beginning of 2014, a trial has been started for another change in the system (11 points $X 5$ rounds). In this condition, it is clear that there will be a change in the physical and mental stress levels of the players and, as a result, a change in their tactics.

In this study, the general analysis of 2012 London Olympics Badminton matches are aimed to be made.

\section{MATERIAL \& METHOD}

In this study, the official website of 2012 London Olympics was used as a means of collecting data (11). During the matches, the results and analysis of total 189 matches (men singles 48, women singles 58, men doubles 29, women doubles 22 and mix doubles 32 matches) published on this site were evaluated. In this study, 90 women with average height of $169.12 \pm 6.12$ $\mathrm{cm}$, average weight of $61.25 \pm 5.18 \mathrm{~kg}$, average age of $25.77 \pm 3.12$ and 80 men with average height of $179.29 \pm 6.47 \mathrm{~cm}$, average weight of $72.78 \pm 7.16 \mathrm{~kg}$ and average age of $27.38 \pm 4.14$ participated from 52 countries.

Descriptive statistical analysis of data (mean, standard deviation, minimum and maximum values, percentage distribution) was done by using SPSS 17.0 Statistical Program.

\section{RESULTS}

As seen in table 1, the average age, the average height and the average weight of the women (no=90) and men $(n o=80)$ players who joined the 2012 Olympics are respectively $25.77 \pm 3.12$ years old, $169.12 \pm 6.12 \mathrm{~cm}, 61.25 \pm 5.18 \mathrm{~kg}$ for women; $27.38 \pm$ $4.14,179.29 \pm 6.47 \mathrm{~cm}, 72.78 \pm 7.16 \mathrm{~kg}$ for men.

At the end of the man singles, the average duration of the match was $45.12 \pm 13.24$ minutes. In rounds, the $3 \mathrm{rd}$ round (with the average of $25.06 \pm 4.2$ minutes) is the longest average round. In rally durations, the 2 nd round (with $41.12 \pm 9.12$ seconds) has the longest duration. The highest average rally strokes are $44.4 \pm 12.8$ times.

\begin{tabular}{|c|c|c|c|c|c|c|}
\hline Variables & & $\mathrm{N}$ & Min. & Max. & Mean & SD \\
\hline \multirow[t]{2}{*}{ Age (year) } & Woman & 90 & 155 & 183 & 169.12 & 6.12 \\
\hline & Man & 80 & 163 & 197 & 179.29 & 6.47 \\
\hline \multirow[t]{2}{*}{ Height $(\mathrm{cm})$} & Woman & 90 & 50 & 75 & 61.25 & 5.18 \\
\hline & Man & 80 & 60 & 95 & 72.78 & 7.16 \\
\hline \multirow[t]{2}{*}{ Weight (kg) } & Woman & 90 & 17 & 38 & 25.77 & 3.12 \\
\hline & Man & 80 & 21 & 37 & 27.38 & 4.14 \\
\hline
\end{tabular}

Table 2. The analysis of man singles (48 matches in total).

\begin{tabular}{|c|c|c|c|c|c|}
\hline & & Min & Max & Mean & SD \\
\hline \multirow[t]{4}{*}{ Match duration (min) } & 1st round & 7 & 28 & 22.18 & 4.12 \\
\hline & 2nd round & 9 & 32 & 22 & 3.54 \\
\hline & 3 rd round & 13 & 28 & 25.06 & 4.2 \\
\hline & Total & 22 & 79 & 45.12 & 13.24 \\
\hline \multirow{4}{*}{$\begin{array}{l}\text { The longest rally duration } \\
\text { (sec) }\end{array}$} & 1 st round & 9 & 65 & 35.31 & 15.78 \\
\hline & 2nd round & 12 & 85 & 41.12 & 9.12 \\
\hline & 3 rd round & 17 & 69 & 34.05 & 14.52 \\
\hline & Total & 17 & 85 & 38.4 & 16.22 \\
\hline \multirow[t]{4}{*}{ The highest rally strokes } & 1st round & 9 & 90 & 34.5 & 13.58 \\
\hline & 2nd round & 17 & 51 & 38.75 & 8.54 \\
\hline & 3 rd round & 14 & 58 & 44.4 & 12.8 \\
\hline & Total & 18 & 90 & 38.66 & 13.26 \\
\hline & & Min & Max & Mean & $\mathrm{SD}$ \\
\hline \multirow[t]{4}{*}{ Match duration (min) } & 1st round & 15 & 25 & 19.2 & 4.04 \\
\hline & 2nd round & 12 & 28 & 20.28 & 4.12 \\
\hline & 3 rd round & 19 & 23 & 21.75 & 5.13 \\
\hline & Total & 20 & 78 & 37.7 & 12.46 \\
\hline \multirow{5}{*}{$\begin{array}{l}\text { The longest rally duration } \\
\text { (sec) }\end{array}$} & 1st round & 8 & 46 & 29.6 & 6.57 \\
\hline & 1st round & 8 & 46 & 29,6 & 6,57 \\
\hline & 2 nd round & 9 & 56 & 30.92 & 8.48 \\
\hline & $3 \mathrm{rd}$ round & 25 & 34 & 30.4 & 9.23 \\
\hline & Total & 16 & 56 & 34.6 & 8.15 \\
\hline \multirow[t]{4}{*}{ The highest rally strokes } & 1st round & 18 & 41 & 23.68 & 8.24 \\
\hline & 2 nd round & 18 & 43 & 23.21 & 7.02 \\
\hline & 3 rd round & 24 & 29 & 25.23 & 5.16 \\
\hline & Total & 18 & 43 & 41.39 & 10.6 \\
\hline
\end{tabular}

In women singles matches, it is seen that the average total match duration is $37.7 \pm 12.4$ minutes and 
the average longest rally duration is $34.6 \pm 8.15$ seconds. The highest average rally stroke is $41.39 \pm 10.6$ times. In common, the three are seen at the 3rd round (Table 3 ).

In men doubles matches, the average total match duration is $39.37 \pm 11.46$ minutes and the average longest rally duration is $38.18 \pm 15.13$ seconds and the highest average rally strokes is $36.74 \pm 12.58$ times (Table 4).

When we observe table 5 , the average total match duration is $42.27 \pm 8.94$ minutes and the average longest rally duration is $48.16 \pm 11.8$ seconds and the highest average rally strokes is $53.39 \pm 15.7$ times.

Table 4 . The analysis of men doubles (29 matches in total).

\begin{tabular}{llcccc}
\hline & & Min & Max & Mean & SD \\
\hline \multirow{3}{*}{ Match duration (min) } & 1st round & 8 & 24 & 19.42 & 4.46 \\
& 2nd round & 9 & 25 & 22.85 & 5.21 \\
& 3rd round & 21 & 28 & 26.45 & 3.25 \\
& Total & 26 & 83 & 39.37 & 11.46 \\
The longest rally duration & & & & & \\
(sec) & 1st round & 16 & 60 & 36.14 & 7.16 \\
& 2nd round & 12 & 67 & 35.42 & 17.57 \\
& 3rd round & 18 & 43 & 32.65 & 5.16 \\
& Total & 16 & 67 & 38.18 & 15.13 \\
& & & & & \\
The highest rally strokes & 1st round & 14 & 72 & 33.28 & 6.26 \\
& 2nd round & 14 & 52 & 39.4 & 11.57 \\
& 3rd round & 18 & 59 & 34.56 & 8.15 \\
& Total & 16 & 63 & 36.74 & 12.58 \\
& & & & & \\
\hline
\end{tabular}

Table 5. The analysis of women doubles (22 matches in total).

\begin{tabular}{|c|c|c|c|c|c|}
\hline & & Min & Max & Mean & SD \\
\hline \multirow{4}{*}{ Match duration (min) } & 1st round & 9 & 26 & 16.42 & 8.44 \\
\hline & 2 nd round & 9 & 24 & 16.71 & 4.25 \\
\hline & 3rd round & 17 & 18 & 17.50 & 3.65 \\
\hline & Total & 20 & 82 & 42.27 & 8.94 \\
\hline \multirow{4}{*}{$\begin{array}{l}\text { The longest rally duration } \\
\text { (sec) }\end{array}$} & 1 st round & 25 & 57 & 39.71 & 20.61 \\
\hline & 2 nd round & 21 & 64 & 36.28 & 22.28 \\
\hline & 3rd round & 24 & 25 & 24.5 & 9.82 \\
\hline & Total & 21 & 64 & 48.16 & 11.8 \\
\hline \multirow{4}{*}{ The highest rally strokes } & 1st round & 28 & 57 & 40.14 & 22.34 \\
\hline & 2 nd round & 22 & 71 & 37.57 & 16.12 \\
\hline & 3rd round & 27 & 28 & 27.5 & 18.5 \\
\hline & Total & 22 & 71 & 53.39 & 15.7 \\
\hline
\end{tabular}

Turk J Sport Exe 2014; I6(3): 55-60

๑ 2014 Department of Physical Education and Sport, Selcuk University
Table 6. The analysis of mix doubles (32 matches in total).

\begin{tabular}{llcccc}
\hline & & Min & Max & Mean & SD \\
\hline \multirow{3}{*}{ Match duration (min) } & & & & \\
& 1st round & 8 & 36 & 20.87 & 6.2 \\
& 2nd round & 12 & 38 & 21.75 & 4.12 \\
& 3rd round & 16 & 42 & 24 & 4.19 \\
& Total & 24 & 76 & 44.27 & 16.44 \\
& & & & & \\
The longest rally duration & 1st round & 15 & 62 & 26.44 & 12.56 \\
(sec) & 2nd round & 17 & 49 & 20.80 & 8.65 \\
& 3rd round & 21 & 50 & 22.33 & 10.12 \\
& Total & 21 & 62 & 23.19 & 9.15 \\
& & & & & \\
The highest rally strokes & 1st round & 14 & 44 & 32.46 & 8.56 \\
& 2nd round & 17 & 58 & 36.42 & 10.24 \\
& 3rd round & 24 & 54 & 34.25 & 8.45 \\
& Total & 24 & 58 & 35.43 & 8.67 \\
& & & & & \\
\hline
\end{tabular}

In the matches played in mix doubles category in 2012 London Olympics, the average total match duration, the average longest rally duration and the highest average rally strokes are $44.27 \pm 16.44$ minutes, $23.19 \pm 9.15$ seconds and $35.43 \pm 8.67$ times respectively (Table 6).

As seen in table 7, China's contribution is the highest in 2012 London Olympics following (15 players - \%8.82), Korea (14 athletes - \%8.24), Denmark and Japan (11 players - \%6.47). 26 countries were represented with 1 player (\%1.11).

While China was the first with 8 medals (5 gold, 2 silver and 1 bronze), Denmark (2 medals), Japan (1 medal), Korea (1 medal), India (1 medal), Malaysia (1 medal) and Russia (1 medal) followed China.

\section{DISCUSSION}

The general analysis of Badminton matches (which took place in 2012 London Olympics) was made. The physical characteristics of the players who participated, the average match duration, the average rally duration, the average rally strokes and the distribution of the athletes according to their countries and how many medals they won were observed.

A total of 170 players (90 women and 80 men) took place in the Olympics. China, with 15 players (8 men and 7 women), is the country that contributed the most (Table 7). To the Athens Olympics in 2004, a total of 162 athletes participated from 30 countries and to the 2008 Beijing Olympics 173 athletes participated from 50 countries. In both of the Olympics, China was 
the one who contributed the most (26 players in 2004, 19 players in 2008). In 2004, 4 countries joined with 1 player and in 2008, 18 countries joined with 1 player (1).

The average age, average height and average weight of the players who took place in the Olympics are respectively $25.77 \pm 3.12$ years old, $169.12 \pm 6.12 \mathrm{~cm}$, $61.25 \pm 5.18 \mathrm{~kg}$ for ladies and $27.38 \pm 4.14$ years old, $179.29 \pm 6.47 \mathrm{~cm}, 72.78 \pm 7.16 \mathrm{~kg}$ for men.

Table 7. The distribution of the countries participated to the2012 London Olympic.

\begin{tabular}{|c|c|c|c|c|c|c|}
\hline Countries & Men & $\%$ & Women & $\%$ & Total & $\%$ \\
\hline 1.CHN & 8 & 10,00 & (1) & 7,78 & 15 & 8,82 \\
\hline 2.MAS & 4 & 5,00 & 2 & 2,22 & 6 & 3,53 \\
\hline 3.KOR & 7 & 8,75 & 7 & 7,78 & 14 & 8,24 \\
\hline 4.DEN & 6 & 7,50 & 5 & 5,56 & 11 & 6,47 \\
\hline $5 . \mathrm{IND}$ & 2 & 2,50 & 4 & 4,44 & 6 & 3,53 \\
\hline 6.JPN & 5 & 6,25 & 6 & 6,67 & 11 & 6,47 \\
\hline $7 . \mathrm{GUA}$ & 1 & 1,25 & & & 1 & 0,59 \\
\hline $8 . N A$ & 5 & 6,25 & 4 & 4,44 & 9 & 5,29 \\
\hline 9.माKG & 1 & 1,25 & 3 & 3,33 & 4 & 2,35 \\
\hline 10.GER & 4 & 5,00 & 2 & 2,22 & 6 & 3,53 \\
\hline 11.ESP & 1 & 1,25 & \begin{tabular}{|l|}
1 \\
\end{tabular} & 1,11 & 2 & 1,18 \\
\hline $12 . \mathbb{R L}$ & 1 & 1,25 & 1 & 1,11 & 2 & 1,18 \\
\hline 13.RUS & 4 & 5,00 & 2 & 2,22 & $\frac{2}{6}$ & 3,53 \\
\hline 14.FIN & 1 & 1,25 & 1 & 1,11 & 2 & 1,18 \\
\hline 15.FRA & 1 & 1,25 & 1 & 1,11 & 2 & 1,18 \\
\hline 16.POR & 1 & 1,25 & 1 & 1,11 & 2 & 1,18 \\
\hline 17.EST & 1 & 1,25 & & & 1 & 0,59 \\
\hline 18.VIE & 1 & 1,25 & & & 1 & 0,59 \\
\hline 19.TUR & & & 1 & 1,11 & 1 & 0,59 \\
\hline $20 . \mathrm{GBR}$ & 2 & 2,50 & 2 & 2,22 & 4 & 2,35 \\
\hline 21.PER & 1 & 1,25 & \begin{tabular}{|l|l|}
1 \\
\end{tabular} & 1,11 & 2 & 1,18 \\
\hline 22.THA & 4 & 5,00 & 2 & 2,22 & 6 & 3,53 \\
\hline 23.SUR & 1 & 1,25 & & & 1 & 0,59 \\
\hline $24 . P O L$ & 4 & 5,00 & 2 & 2,22 & 6 & 3,53 \\
\hline $25 . \mathrm{SIN}$ & 1 & 1,25 & 3 & 3,33 & 4 & 2,35 \\
\hline $26 . \mathrm{UKR}$ & 1 & 1,25 & \begin{tabular}{|l|}
1 \\
\end{tabular} & 1,11 & 2 & \begin{tabular}{|l|}
1,18 \\
\end{tabular} \\
\hline 27. UGA & 1 & 1,25 & & 0,00 & 1 & 0,59 \\
\hline 28.TPE & 3 & 3,75 & 5 & 5,56 & 8 & 4,71 \\
\hline 29.SWE & 1 & 1,25 & & & 1 & 0,59 \\
\hline $30 . \mathrm{CZE}$ & 1 & 1,25 & 1 & 1,11 & 2 & 1,18 \\
\hline 31.AUT & 1 & 1,25 & 1 & 1,11 & 2 & 1,18 \\
\hline 32.MDV & 1 & 1,25 & & & 1 & 0,59 \\
\hline 33.BEI & 1 & 1,25 & 1 & 1,11 & 2 & \begin{tabular}{|l|}
1,18 \\
\end{tabular} \\
\hline 34. ISR & 1 & 1,25 & & & 1 & 0,59 \\
\hline $35 \mathrm{NED}$ & & & 1 & 1,11 & 1 & 0,59 \\
\hline $36 . \mathrm{BUL}$ & & & 1 & 1,11 & 1 & 0,59 \\
\hline 37.CAN & & & 3 & 3,33 & 3 & 1,76 \\
\hline $38 . \Pi \mathrm{TA}$ & & & 1 & 1,11 & 1 & 0,59 \\
\hline 39.INA & & & 1 & 1,11 & 1 & 0,59 \\
\hline 39. USA & & & 1 & 1,11 & 1 & 0,59 \\
\hline $40 . \mathrm{MEX}$ & & & $\mid 1$ & 1,11 & 1 & 0,59 \\
\hline $41, \mathrm{SUI}$ & & & \begin{tabular}{|l|}
1 \\
\end{tabular} & 1,11 & $\mid 1$ & $\begin{array}{l}0,59 \\
\end{array}$ \\
\hline $42 . \mathrm{FIN}$ & & & 1 & 1,11 & 1 & 0,59 \\
\hline $43 . \mathrm{ISL}$ & & & \begin{tabular}{|l|}
1 \\
\end{tabular} & 1,11 & 1 & 0,59 \\
\hline 44.AUS & 2 & 2,50 & 3 & 3,33 & 5 & 2,94 \\
\hline $45 . S L O$ & & & \begin{tabular}{|l|}
1 \\
\end{tabular} & 1,11 & 1 & 0,59 \\
\hline $46 . \mathrm{LTU}$ & & & \begin{tabular}{|l|}
1 \\
\end{tabular} & 1,11 & $\mid 1$ & 0,59 \\
\hline 47.PER & & & 1 & 1,11 & 1 & 0,59 \\
\hline 48.SVK & & & 1 & 1,11 & 1 & 0,59 \\
\hline 49.BLR & & & 1 & 1,11 & 1 & 0,59 \\
\hline $50 . \mathrm{EGY}$ & & & 1 & 1,11 & 1 & 0,59 \\
\hline 51.NOR & & & 1 & 1,11 & 1 & 0,59 \\
\hline 52.SRI & & & 1 & 1,11 & 1 & 0,59 \\
\hline Total & 80 & 100,0 & 90 & 100,0 & 170 & 100,0 \\
\hline
\end{tabular}

Table 8. The distribution of medals in 2012 London Olympics.

\begin{tabular}{|c|c|c|c|}
\hline \multirow{2}{*}{ Categories } & \multicolumn{3}{|c|}{ The Distribution of medals in 2012 London Olympics } \\
\cline { 2 - 4 } & Gold & Silver & Bronze \\
\hline Lady Singles & China & China & India \\
\hline Man Singles & China & Malaysia & China \\
\hline Ladies Double & China & Japan & Russia \\
\hline Men Double & China & Danemark & Korea \\
\hline Mix Double & China & China & Danemark \\
\hline
\end{tabular}


In the study that Senel \& Eroglu (15) conducted in 2005, it is clearly seen that for ladies the average age is 25.59 , the average weight is $62.2 \mathrm{~kg}$ and the average height is $168.3 \mathrm{~cm}$. In the research that Revan et al. (4) conducted in 2007 on elite badminton players, the average weight and height of the national players of the Turkish National Badminton Team are 175.0 \pm 7.3 $\mathrm{cm}$ and $67.5 \pm 7.7 \mathrm{~kg}$ for men; $166.4 \pm 5.6 \mathrm{~cm}$ and $59.5 \pm 7.7$ $\mathrm{kg}$ for women. The players of the 2008 Beijing Olympic Games' average age, average height and average weight are respectively $25.16 \pm 3.7,168.32 \pm 6.28$ $\mathrm{cm}, 61.66 \pm 5.97 \mathrm{~kg}$ for women and $27.12 \pm 4.02$, $178.98 \pm 6.48 \mathrm{~cm}, 73.47 \pm 7.59 \mathrm{~kg}$ for men (1).

In man singles match durations, the average duration for the 1st round is $22.18 \pm 4.12$ minutes, for the 2 nd round is $22 \pm 3.54$ minutes and for the $3 \mathrm{rd}$ round is $25.06 \pm 4.2$ minutes and the total duration is $45.12 \pm 13.24$ minutes. In lady singles the average durations for each round are respectively 19.2 \pm 4.04 minutes, $20.28 \pm 4.12$ minutes and $21.75 \pm 5.13$ minutes and the total duration is $37.7 \pm 12.46$ minutes. In men doubles the average durations for each round are respectively $19.42 \pm 4.46$ minutes, $22.85 \pm 5.21$ minutes and $26.45 \pm 3.25$ minutes and the total duration is $39.37 \pm 11.46$ minutes. In ladies doubles the average durations for each round are respectively $16.42 \pm 8.44$ minutes, $16.71 \pm 4.25$ minutes, $17.5 \pm 3.65$ minutes and the total duration is $42.27 \pm 8.94$ minutes. And lastly in mix doubles we see that the average durations for each round are respectively $20.87 \pm 6.2$ minutes, $21.75 \pm 4.32$ minutes, $24 \pm 4.19$ minutes and the total duration is $44.27 \pm 16.44$ minutes.

In the study that Cinemre et al. (7) conducted on young badminton players, they found out that in the lady singles the average duration for the 1st round is $4.50 \pm 2.21$ minutes and for the 2 nd round is $6.01 \pm 1.69$ minutes and in the man singles the average duration for the 1st round is $10.15 \pm 3.25$ minutes and for the 2 nd round is $16.91 \pm 7.26$ minutes. Aydogmus determined in his 2002 study that Turkish National Men Badminton players played 33.78 minutes in total (2). In another research which Aydogmus et al. (3) conducted, they found out that in $3 \times 15$ point system the average duration is 33.78 minutes and in $5 \times 7$ point system it is 27.21 minutes.

In a study conducted on 8 women and 8 men about match analysis, it is determined that in 21 point system, the average match duration for men is 17.27

Turk J Sport Exe 2014; I6(3): 55-60

๑ 2014 Department of Physical Education and Spart, Selcuk University minutes and for women it is 17.14 minutes (12). In 2008 Olympics, in men singles, this duration is approximately 41.7 minutes (1).

When we look at the longest rally durations in the matches, the average of man singles for the 1st round is $35.31 \pm 15.78$ seconds, for the 2 nd round is $41.12 \pm 9.12$ seconds and for the 3rd round is $34.05 \pm 14.52$ seconds and the mean of these 3 rounds is $38.4 \pm 16.22$ seconds. In lady singles the average for each round are respectively $29.6 \pm 6.57$ seconds, $30.92 \pm 8.48$ seconds and $30.4 \pm 9.23$ seconds and the mean for the longest rally duration of these 3 rounds is $34.6 \pm 8.15$ seconds. In men doubles the average for each round are respectively $36.14 \pm 7.16$ seconds, $35.42 \pm 17.57$ seconds and $32.65 \pm 5.16$ seconds and the mean of these 3 rounds is $38.18 \pm 15.13$ seconds. In ladies doubles the average for each round are respectively $39.71 \pm 20.61$ seconds, $36.28 \pm 22.28$ seconds and $24.5 \pm 9.82$ seconds and the mean of these 3 rounds is $48.16 \pm 11.8$ seconds. And lastly in mix doubles we see that the average rally durations for each round are respectively $26.44 \pm 12.56$ seconds, $20.80 \pm 8.65$ seconds, $22.33 \pm 10.12$ seconds and the mean of 3 rounds is

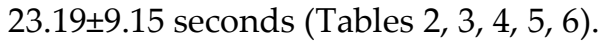

In the study which Cabello and Gonzales worked on in 2003 (6), they defined the match duration as 28 minutes, the rally duration as 6.4 seconds and break times as 12.9 seconds. Again, Cabello et al. (5) state that the rally duration is 8 seconds and the time to rest is twice of it (16 seconds) according to their research on three high-level national players.

When the highest rally strokes are observed in the matches, it is seen that in man singles in the 1st round it is $34.5 \pm 13.58$ times, in the $2 \mathrm{nd}$ it is $38.75 \pm 8.54$ times, in the $3 \mathrm{rd}$ it is $44.4 \pm 12.8$ times and the mean of these 3 rounds is $38.66 \pm 13.26$ times. In lady singles in the 1 st round it is $23.68 \pm 8.24$ times, in the 2 nd it is $23.21 \pm 7.02$ times, in the $3 \mathrm{rd}$ it is $25.23 \pm 5.16$ times and the mean of these 3 rounds is $41.39 \pm 10.6$ times. In men doubles in the 1st round it is $33.28 \pm 6.26$ times, in the 2nd it is $39.4 \pm 11.57$ times, in the $3 \mathrm{rd}$ it is $34.56 \pm 8.15$ times and the mean of these 3 rounds is $36.74 \pm 12.58$ times. In ladies doubles in the 1st round it is $40.14 \pm 22.34$ times, in the 2 nd it is $37.57 \pm 16.12$ times, in the $3 \mathrm{rd}$ it is $27.5 \pm 18.5$ times and the mean of these 3 rounds is $53.39 \pm 15.7$ times. And at last, in mix doubles, it is seen that in the 1st round it is $32.46 \pm 8.56$ times, in the $2 \mathrm{nd}$ it is $36.42 \pm 10.24$ times, in the $3 \mathrm{rd}$ it is $34.25 \pm 8.45$ times and the mean of these 3 rounds is 
35.43 \pm 8.67 times (Tables 2, 3, 4, 5, 6).

The difference between 2012 London Olympics and the previous two Olympic Games is the countries which participated and the number of the players. When there were 162 participants from 30 countries (76 women, 86 men) in 2004 Olympics, this number has increased to 173 participants from 50 countries (86 women, 87 men). In 2012 London Olympics this number has become 170 participants from 52 countries (90 women, 80 men). While China is the first with 8 medals (5 gold, 2 silver and 1 bronze) in 2012 London, Denmark follows China with 2 medals (1 silver and 1 bronze).

To conclude the study, we can say that not the match durations but the rally durations and the strokes being more in ladies doubles can be related with women having less strength than men and ending strokes such as smashes being less. Furthermore, we can explain why these parameters don't reflect on match durations by the reduction in the number of continuous matches. In mixed doubles categories, rather than the rally durations and the number of strokes, tactic is on the forefront. In the game, rapid strokes like smashes and drives are generally used and we can say that this type of game shortens the rally durations of the match.

As a result, according to the 2012 London Olympics analysis, badminton coaches and players must revise technical, tactical, conditional elements of badminton and they have to prepare special schedules for category properties.

\section{REFERENCES}

1. Arslanoğlu E, Arslan Y, Şenel Ö. Analysis of badminton competitions In 2008 Beijing Olympic Games and comparison with the 2004 Olympic Games. Spormetre Beden Eğitimi ve Spor Bilimleri Dergisi, 2009; 7(2):77-84.

2. Aydoğmuş M. Badmintonda Farklı Skor Sistemlerinin Oyuncuların Bazı Yorgunluk Parametreleri Üzerindeki Etkileri. G.Ü. Sağlık Bilimleri Enstitüsü, Yüksek Lisans Tezi, Ankara, 2002.
3. Aydoğmuş M, Şenel Ö, Bukan N, Güzel NA. Farklı skor sistemlerine badminton oyuncularinin fizyolojik ve metabolik cevaplari. Gazi Beden Eğitimi ve Spor Bilimleri Dergisi, 2006; 11(2):11-18.

4. Baron R, Petschnig R, Bachl N, Raberger G, Smekal G, Kastner P. Catecholamine excretion and heart rate as factors of psychophysical stress in table tenis. Int J Sports Med, 1992; 13(7): 501-505.

5. Cabello D, Cruz JC, Padial P. Estudio de la Frecuencia Cardiaca y Acido Lactico en Badminton. In: VIII Congresso Europeo de Medicana del Deporte, Granada, October, 1995 (Cited in Cabello and et al 2003).

6. Cabello D, Gonzales JJ. Analysis of the characteristics of competitive badminton. Br J Sports Med, 2003; 37: 62-66.

7. Cinemre A, Açıkada C, Hazır T, Şenel Ö. Evaluation of lactate and heart rate values of young badminton players during the match. Hacettepe Journal of Sport Science, 2002; 13(4):22-31.

8. Demirci N. A'dan Z'ye Spor. Neyir Yayıncılık ve Matbaacılık, Ankara, 1995.

9. Faccini C, Dal Monte A. Physiologic demands of badminton. The Am J of Sports Med, 1996; 24:64-68.

10. Faude O, Meyer T, Rosenberger F, Fries M, Huber G, Kindermann W. Physiological characteristics of badminton match play. Eur J Appl Physiol, 2007; 100:479-485.

11. http://www.olympic.org/Documents/Reports/Official\%20Past\% 20Games\%20Reports/Summer/ENG/2012-RO-S-

London_official_results.pdf

12. Ming CL, Keong CC, Ghosh AK. Time motion and notational analysis of 21 point and 15 point badminton match play. International Journal of Sports Science and Engineering, 2008; 2(4):216-222.

13. Omosegaard B. Physical Training for Badminton. Denmark. Melling Beck, 1996.

14. Revan S, Aydoğmuş M, Balcı SS, Pepe H, Eroğlu H. The evaluation of some physical and physiological characteristics of Turkish and foreign national badminton team players. Nigde University J of Physical Education and Sport Sciences, 2007; 1(2):1-8.

15. Şenel Ö, Eroğlu H. 2004 Atina Olimpiyat Oyunları badminton müsabakalarinin analizi. Gazi Beden Eğitimi ve Spor Bilimleri Dergisi, 2005; 10(4):49-58. 